\title{
Main Characteristics of Mexico City Local Wind Events during the MILAGRO 2006 Campaign within a Meso- $\beta$ Scale Lattice Wind Modeling Approach
}

\author{
Ana-Teresa Celada-Murillo, ${ }^{1}$ Susana Carreón-Sierra, ${ }^{1,2,3}$ Alejandro Salcido, ${ }^{1}$ Telma Castro, ${ }^{4}$ \\ Oscar Peralta, ${ }^{4}$ and Teodoro Georgiadis ${ }^{5}$ \\ ${ }^{1}$ División de Energías Alternas, Instituto de Investigaciones Eléctricas, Reforma 113, Palmira, 62490 Cuernavaca, MOR, Mexico \\ ${ }^{2}$ División de Matemáticas e Ingeniería, Programa de Matemáticas Aplicadas y Computación, Facultad de Estudios Superiores Acatlán, \\ Universidad Nacional Autónoma de México, Avenida San Juan Totoltepec s/n, Santa Cruz Acatlán, 53150 Naucalpan, MEX, Mexico \\ ${ }^{3}$ International Institute for Learning México S.A. de C.V., Prado Sur 240-303, Lomas de Chapultepec, Miguel Hidalgo, \\ 11000 Mexico City, DF, Mexico \\ ${ }^{4}$ Centro de Ciencias de la Atmósfera, Universidad Nacional Autónoma de México, Circuito Exterior, Ciudad Universitaria, 04510 \\ Mexico City, DF, Mexico \\ ${ }^{5}$ Istituto di Biometeorologia, Consiglio Nazionale delle Ricerche (IBIMET-CNR), Via Gobetti 101, 40129 Bologna, Italy
}

Correspondence should be addressed to Alejandro Salcido; vasalcido@gmail.com

Received 29 November 2012; Accepted 17 December 2012

Academic Editors: N. A. Mazzeo and D. Moreira

Copyright (c) 2013 Ana-Teresa Celada-Murillo et al. This is an open access article distributed under the Creative Commons Attribution License, which permits unrestricted use, distribution, and reproduction in any medium, provided the original work is properly cited.

\begin{abstract}
A characterization of local wind events in Mexico City, which occurred during MILAGRO campaign, was carried out within the framework of a lattice wind modeling approach at a meso- $\beta$ scale. Mexico City was modeled as a 2D lattice domain with a given number of identical cells. Local wind conditions at any cell were described by a state variable defined by the spatial averages of wind attributes such as speed, direction, divergence, and vorticity. Full and partial densities of wind states were discussed under different conditions using two simple lattice wind models. We focus on the results obtained with the 1-cell lattice wind model and provide brief comments about preliminary results obtained with the 4-cell model. The 1-cell model allowed identifying the main patterns of the wind circulation in Mexico City throughout the study period (anabatic and katabatic winds, winds induced by the urban heat island, and winds with high possibilities for exchanging pollutants between Mexico City and the neighboring settlements, among others). The model showed that Mexico City wind divergence and vorticity disclose superposed oscillations whose most important periods were 24 and 12 hours, suggesting strong connections with the diurnal cycle of incoming solar radiation and the urban heat island.
\end{abstract}

\section{Introduction}

Poor air quality is a common problem in the world biggest cities due to the atmospheric emissions derived from the anthropogenic impact on the environment. Also, topography and meteorology may increase the severity of local air pollution. So, local wind circulation is particularly important for estimating transport and dispersion of air pollutants, and consequently for carrying out air quality assessment studies and assessing the export of air pollutants to neighboring human settlements.
The best description of wind circulation is provided by the eulerian wind velocity field. However, in practical problems of meteorology and air pollution, wind flow involves a number of complex features (turbulent regime, complex terrain, unsolvable difficulties for establishing initial and boundary conditions, etc.) and no analytical expression can be obtained for wind velocity field. Then, numerical solutions provided by computational models (such as MM5 and other mesoscale meteorological models) and also simple analysis and diagnostic approaches (such as wind roses and 
constrained interpolation techniques) are well appreciated in general for describing wind circulation when complex features (such as topography) are involved.

In this paper, a simple and innovative wind modeling approach proposed by Salcido and collaborators [1-3] is described and then applied to perform a characterization study of the Mexico City local wind events which prevailed during the MILAGRO campaign (March 2006). Mexico City area was modeled as a two-dimensional lattice domain with a given number of identical cells. Local wind conditions at any lattice cell were described by a discrete wind state variable, which is defined in terms of spatial average values of wind attributes of speed, direction, divergence, and vorticity; all expressed in convenient discrete measuring scales. The inclusion of the wind's divergence and vorticity describing local wind condition at a lattice cell constitutes an extension of local wind state variables that gives a slightly nonlocal character to lattice wind models. With two of the simplest lattice wind models (the one-cell model and the four-cell model), wind data reported by the official atmospheric monitoring network (REDMET-SIMAT) of the Mexico City Metropolitan Area (MCMA) were elaborated obtaining several sets of hourly meso- $\beta$ scale wind states that occurred in Mexico City throughout March 2006. The densities of discrete wind states were calculated and analyzed for different conditions (diurnal and nocturnal conditions, given time periods, etc.), allowing the identification of wind patterns and characteristics.

The general characteristics of the local wind behavior in the MCMA boundary layer, its driving forces, and its relations with air pollution and urban climate were discussed more than two decades ago. In 1988, Jáuregui analyzed the interactions between local winds and air pollution in the Mexico basin [4], and in 1997, he studied the heat island development in Mexico City [5]. In 1997, Bossert studied the flow regimes affecting the Mexico City region [6], and in 1998, Fast and Zhong [7] and Doran et al. [8] studied meteorological factors associated with air pollution, and particularly with the ozone concentrations in Mexico City basin. In 2003, Salcido et al. reported the first longterm surface micrometeorological campaign carried out in MCMA in 2001 [9], and also statistical analysis of convective mixing height in Mexico City [10]. In relation with the MILAGRO campaign, many interesting results were reported in the last years: De Foy et al. in 2005 described the Mexico City basin wind circulation during a previous short-term campaign carried out in 2003 [11]; Fast et al. in 2007, and de Foy et al. in 2008, reported a meteorological overview of MILAGRO campaign [12], and a basin-scale study of wind transport and its comparison to climatology for MILAGRO campaign [13], respectively.

The main characteristics we found for the Mexico City local winds were in agreement with the wind patterns described by the above-mentioned authors; however, the lattice wind modeling approach was also able to provide more detailed description of wind circulation events and to reveal new characteristics as a result of including additional wind state variables properties, like divergence and vorticity.

\section{The Lattice Wind Modeling Approach}

The lattice wind modeling approach consists in representing the spatial region of interest by a $2 \mathrm{D}$ lattice domain made up of a given number $N$ of identical rectangular cells: $N=$ $N_{x} \times N_{y}$, where $N_{x}\left(N_{y}\right)$ denotes the number of cells along the west-east (south-north) direction. Each cell is invested with a wind state (WS) variable that describes local wind conditions in the cell in terms of four parameters $(U, \theta$, $\gamma$, and $\omega$ ), where $U$ is wind speed, $\theta$ is wind direction, and $\gamma$ and $\omega$ denote the wind's divergence and vorticity (as they are usually defined in meteorology in terms of the horizontal components of the wind velocity field). The values of state parameters are understood as spatial averages over the lattice cell. The inclusion of divergence and vorticity, as additional wind state variables, endows the model with a slightly nonlocal character and allows recovering some wind behavior information lost by the filtering due to spatial averaging process of the wind velocity over each cell. Thus, besides the mean velocity, its tendencies of rotation and divergence on each cell are assumed to be known.

From the local equilibrium hypothesis of linear fluid mechanics point of view, a lattice wind model (LWM) becomes overdetermined in the limit $N \rightarrow \infty$, or more precisely $N_{x} \rightarrow \infty$ and $N_{y} \rightarrow \infty$. However, in some extended thermodynamic theories, the gradients of the velocity field have been considered as additional state variables, and this extension allows finding out nonlinear constitutive equations for non-Newtonian fluids [14].

Under an LWM, the spatial complexity of the wind velocity field is mapped into an $N_{x} \times N_{y}$ matrix $\xi(t)$, defined by cell wind states $(U, \theta, \gamma, \omega)_{i j}$. The wind state in the lattice is represented by this matrix.

When the values of the state parameters $(U, \theta, \gamma$, and $\omega)$ are expressed in terms of finite and discrete scales, such as the Beaufort wind speed scale, a $N_{\theta}$ sectors scale for wind direction, a $N_{\gamma}$ levels scale for wind divergence, and a $N_{\omega}$ levels scale for wind vorticity, the wind states are referred to as discrete wind states (DWSs), and each DWS can be identified by a nonnegative integer number $\varepsilon$ given by

$$
\varepsilon=\omega+N_{\omega}\left[\gamma+N_{\gamma}\left(\theta+N_{\theta} U\right)\right] .
$$

For any lattice cell, the number of all possible DWS will be the product of the numbers of levels of wind speed $\left(N_{v}\right)$, wind direction $\left(N_{\theta}\right)$, divergence $\left(N_{\gamma}\right)$, and vorticity $\left(N_{\omega}\right)$ :

$$
N_{s}=N_{v} \times N_{\theta} \times N_{\gamma} \times N_{\omega} .
$$

For purposes of this work, we consider the DWS in terms of Beaufort wind speed scale, wind direction scale with $N_{\theta}=$ $8(N=0, \mathrm{NE}=1, E=2, \mathrm{SE}=3, S=4, \mathrm{SW}=5, W=$ 6 , and NW $=7)$, wind divergence scale with $N_{\gamma}=3(0=$ convergent, $1=$ parallel, and $2=$ divergent), and vorticity scale with $N_{\omega}=3$ also $(0=$ anticyclonic (clockwise rotation), $1=$ no rotation, and 2 = cyclonic (counterclockwise rotation)).

In the case of the 4-cell LWM, we have found useful the wind direction state (WDS) concept, with $N_{\theta}=8$, which is defined by four mean wind directions $\theta_{\mathrm{NE}}, \theta_{\mathrm{NW}}, \theta_{\mathrm{SW}}$, and $\theta_{\mathrm{SE}}$ 
(each expressed in 8-sectors-scale) at cells (or quadrants) NE, NW, SW, and SE of the lattice domain, respectively. WDS can be conveniently identified by a four-digit octal number $(0000$, ..., 7777) or its decimal equivalent.

It must be observed that not all wind states will be necessarily observed at the region of interest. It depends on topographical features and the particular wind driving forces existing in the region. The relative frequency distribution of wind states, hereafter referred to as the density of wind states (DOWSs), constitutes a convenient way to identify the probability of occurrence for each wind state under different conditions (specific time periods, season, daytime, nighttime, etc.); it gives the fraction of times that a given state was present at the region of interest within a given period of time.

\section{Study Area and Its Main Characteristics}

This work is focused on Mexico City, the most important part of MCMA. It lies inside the Basin of Mexico, between 19.05 and 19.60 degrees north latitude, and 98.95 and 99.35 degrees west longitude, and it has an average altitude of $2240 \mathrm{~m}$.

3.1. Topography. The Basin of Mexico City belongs to the Neovolcanic Axis and it is almost completely surrounded by high mountains [15], as it is shown in Figure 1. To the north, with the Sierra de Guadalupe creating a small $800 \mathrm{~m}$ barrier above the ground, the basin extends into the Mexican plateau and the arid interior of the country. To the west, lies the Sierra de las Cruces, a range $65 \mathrm{~km}$ long with altitudes surpassing 3300 meters, although the terrain altitude decreases below the $3000 \mathrm{~m}$ close to the middle of the range (around 19.3 degrees north). To the south, lies the Sierra del Ajusco-Chichinautzin, with the Ajusco volcano as the most prominent feature (3930 $\mathrm{m}$ altitude). This range extends eastward to about 98.9 degrees west; thereafter the terrain altitude decreases below $2500 \mathrm{~m}$, creating a mountain gap, $22 \mathrm{~km}$ long, which ends at the Iztaccihuatl mountain. Finally, to the east lies the Sierra Nevada; it is a range $70 \mathrm{~km}$ long which extends from the Popocatepetl volcano (5426 m altitude) at the south up to the hills that descend from the Monte Tláloc at the north.

3.2. Climate. The Mexico City climate has been classified into two seasons: rainy season, from May to October, and dry season, from November to April. This classification comes from the two main meteorological patterns on the synoptic scale: dry westerly winds with anticyclone conditions from November to April, and moist flows from the east due to weaker trade winds during the other six months [4]. However, Mexico City's meteorology is more complex. Important interactions of the basin with the Mexican plateau and lower coastal areas may occur. Moreover, it is common to have weak large-scale pressure gradients and strong solar radiation throughout the year $[4,9,13,15]$. These conditions, combined with the surrounding mountains, are ideal for the development of thermally driven winds, such as anabatic and katabatic winds, and also winds driven by the heat island phenomenon.
TABLE 1: Stations of MCMA meteorological monitoring network (REDMET-SIMAT).

\begin{tabular}{|c|c|c|c|c|c|c|c|}
\hline \multirow{2}{*}{ ID } & \multirow{2}{*}{ Station name } & \multicolumn{2}{|c|}{ Position } & \multicolumn{4}{|c|}{ Parameters } \\
\hline & & LAT & LON & WSP & WDR & TEM & $\mathrm{RH}$ \\
\hline TAC & Tacuba & 19.455 & -99.202 & 1 & 1 & 1 & 1 \\
\hline EAC & Acatlán & 19.482 & -99.243 & 1 & 1 & 1 & 1 \\
\hline SAG & San Agustín & 19.532 & -99.030 & 1 & 1 & 1 & 1 \\
\hline TLA & Tlanepantla & 19.528 & -99.204 & 1 & 1 & 1 & 1 \\
\hline XAL & Xalostoc & 19.528 & -99.076 & 1 & 1 & 1 & 1 \\
\hline MER & La Merced & 19.424 & -99.119 & 1 & 1 & 1 & 1 \\
\hline PED & Pedregal & 19.325 & -99.204 & 1 & 1 & 1 & 1 \\
\hline CES & $\begin{array}{l}\text { Cerro de la } \\
\text { Estrella }\end{array}$ & 19.336 & -99.075 & 1 & 1 & 1 & 1 \\
\hline PLA & Plateros & 19.367 & -99.200 & 1 & 1 & 1 & 1 \\
\hline HAN & Hangares & 19.422 & -99.084 & 1 & 1 & 1 & 1 \\
\hline CUA & Cuajimalpa & 19.364 & -99.299 & 1 & 0 & 0 & 1 \\
\hline TPN & Tlálpan & 19.256 & -99.184 & 1 & 0 & 0 & 1 \\
\hline CHA & Chapingo & 19.460 & -98.902 & 1 & 0 & 0 & 1 \\
\hline TAH & Tláhuac & 19.246 & -99.010 & 1 & 0 & 1 & 1 \\
\hline VIF & $\begin{array}{c}\text { Villa de las } \\
\text { Flores } \\
\end{array}$ & 19.658 & -99.097 & 0 & 1 & 1 & 1 \\
\hline
\end{tabular}

LAT: latitude, LON: longitude, WSP: wind speed, WDR: wind direction, TEM: temperature, and RH: relative humidity.

\section{Wind Data}

The MILAGRO campaign was carried out on March 2006 in Mexico City Metropolitan Area (MCMA). It was an international scientific collaborative effort focused on the study of local, regional, and global impacts of megacity air pollution, using as a case study MCMA and its surrounding areas [16]. This urban area was selected as a case study for the MILAGRO campaign because it has a tropical latitude similar to other megacities, it receives a large amount of incoming solar radiation all year long making its atmosphere extremely active photochemically, which promotes the transformation of atmospheric pollutants; but also because of the existence of reliable urban and air quality measurement, with the official air quality and meteorological monitoring networks, providing hourly records systematically.

The MCMA atmospheric monitoring system (SIMAT) has 36 stations: 24 located in Mexico City and 12 in the State of Mexico. Among them, 15 stations measure local meteorology (wind speed, wind direction, temperature, and relative humidity) and provide reliable and systematic reports of average values in an hourly basis [17]. The meteorology subnetwork of SIMAT is known as REDMET. The names, IDs, and geographical coordinates of REDMET stations are presented in Table 1, and their spatial distribution is shown in Figure 1.

The database we used for carrying out this study comprises hourly reports of wind speed and wind direction provided by REDMET throughout March 2006. It is a database with 744 hourly events describing the local meteorology conditions which prevailed at MCMA during MILAGRO 


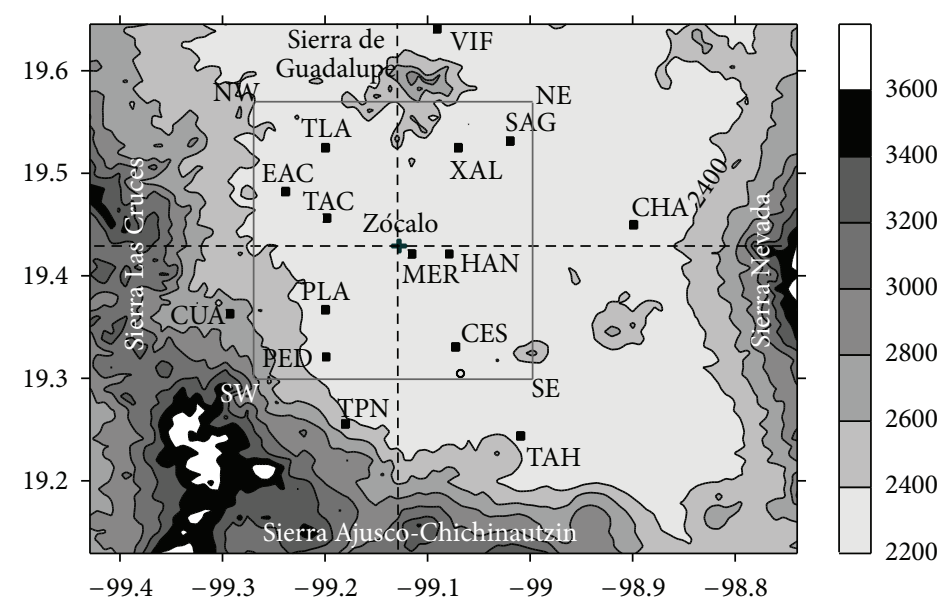

Figure 1: Topographic features of Mexico City Metropolitan Area. The lattice domains used in the 1-cell (solid line rectangle) and the 4cell (solid line rectangle divided by dotted lines) lattice wind models are shown. The positions of the stations of the meteorological network (REDMET-SIMAT) are also shown (small solid squares).

campaign. During this time, the average performance of REDMET was $90 \%$ with respect to wind data.

\section{Mexico City Wind States}

For the lattice wind modeling purposes, the spatial domain we considered was the Mexico City region located at north latitudes extending from $19.30^{\circ}$ to $19.57^{\circ}$ and west longitudes extending from $99.00^{\circ}$ to $99.27^{\circ}$. This area was considered as the single cell in the 1-cell LWM, but for the purposes of the 4-cell LWM, it was divided into the quadrants NE, NW, SW, and SE, defined by west-east and south-north axes shown in Figure 1 (dotted lines). The origin of this reference frame was set at the geometric center defined by the station positions of Mexico City atmospheric monitoring network. This point is $2 \mathrm{~km}$ to the NE of the Zócalo (the main place in the heart of the city's historic center). The geometric centers coordinates of the lattice cells were $\left(19.499^{\circ} \mathrm{N}, 99.067^{\circ} \mathrm{W}\right)$ for $\mathrm{NE}$ cell; $\left(19.499^{\circ} \mathrm{N}, 99.200^{\circ} \mathrm{W}\right)$ for $\mathrm{NW}$ cell; $\left(19.366^{\circ} \mathrm{N}, 99.200^{\circ} \mathrm{W}\right)$ for SW cell; $\left(19.366^{\circ} \mathrm{N}, 99.067^{\circ} \mathrm{W}\right)$ for SE cell. Horizontal cell dimensions were $L_{\mathrm{WE}}=14.0 \mathrm{~km}$ in west-east direction, and $L_{\mathrm{SN}}=18.5 \mathrm{~km}$ in south-north direction. The cell height was assumed no larger than the surface layer depth. Because of the lattice cell dimensions, this description will correspond to a meso- $\beta$ scale representation of Mexico City wind events.

Using the 1-hour average data of wind speed and wind direction provided by REDMET [17], wind speed $U$, wind direction $\theta$, wind divergence $\gamma$, and wind vorticity $\omega$ were estimated at the geometric centers of the lattice cells. The frameworks of 1-cell and 4-cell lattices wind models of Mexico City were considered.

The procedure was as follows: for each hour of the study period, wind speed and wind direction of all meteorological stations of REDMET were used to estimate the wind velocity components at each site of a $8 \times 8$ regular grid (immersed in the study domain) using a boundary-constrained vector interpolation technique of Kriging type; then results were used to calculate the spatial averages of wind state parameters
$(U, \theta, \gamma$, and $\omega)$ at each cell of LWM, and the corresponding discrete wind states (DWS) were calculated in terms of Beaufort scale for wind speed, the scale with $N_{\theta}=8$ for wind direction, and the scales with $N_{\gamma}=3$ and $N_{\omega}=$ 3 for wind divergence and wind vorticity, respectively. The relative frequency distributions were determined for the DWS occurred during the study period and then analyzed to recognize the main wind patterns of the same period.

\section{Results and Discussion}

The densities of discrete wind states that occurred during March 2006 in Mexico City are presented in this section. For each wind state, the density of DWS gives the fraction of times (expressed in \%) that this state is found within the full set of the observed DWS (or within a given specific subset of them). The states with the highest frequencies of occurrence are indicated explicitly, including a visual representation of them. The plots of the density of states show the highest frequencies states with the integer identification $\varepsilon$ followed by values of state parameters $(U, \theta, \gamma$, and $\omega)$, expressed in the form $[U: \theta: \gamma: \omega]$. The visual representation of a DWS is composed by one oriented circle, two oriented secants (arrows), and one small circle (inside of and concentric with the oriented circle) with a nonnegative integer written inside. The oriented circle represents the wind vorticity, the oriented secants represent both wind direction and wind divergence, and the number inside the small circle denotes wind speed in the Beaufort scale.

6.1. Results from the 1-Cell Lattice Wind Model. As a first approximation, the Mexico City area was considered as a single cell and its local wind conditions were described by spatial averages of state parameters $(U, \theta, \gamma$, and $\omega)$ over the region. The time series of the wind state parameters are shown in Figure 2 for the complete study period. 




(a)

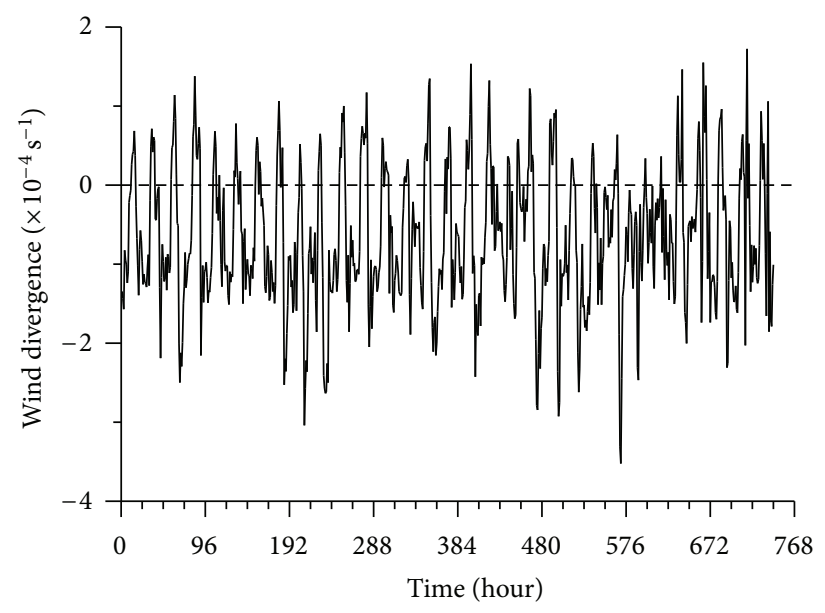

(c)

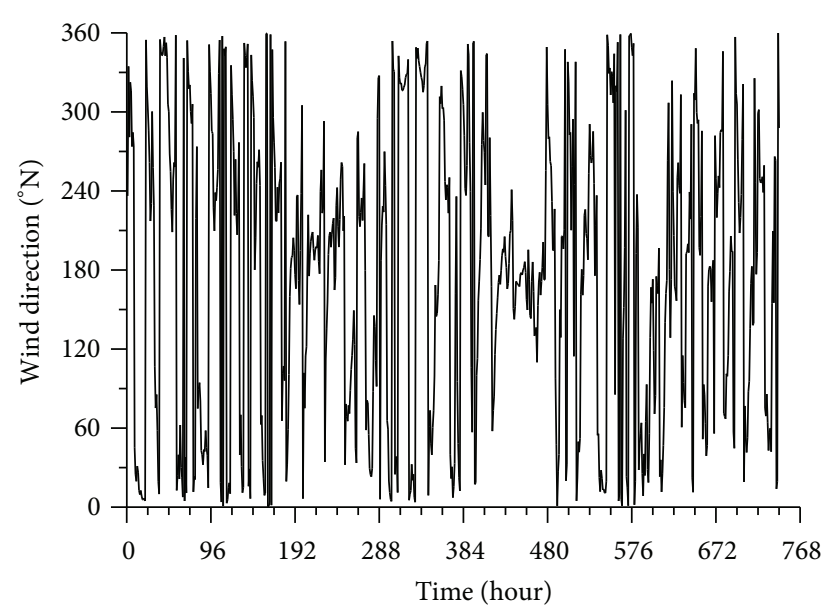

(b)

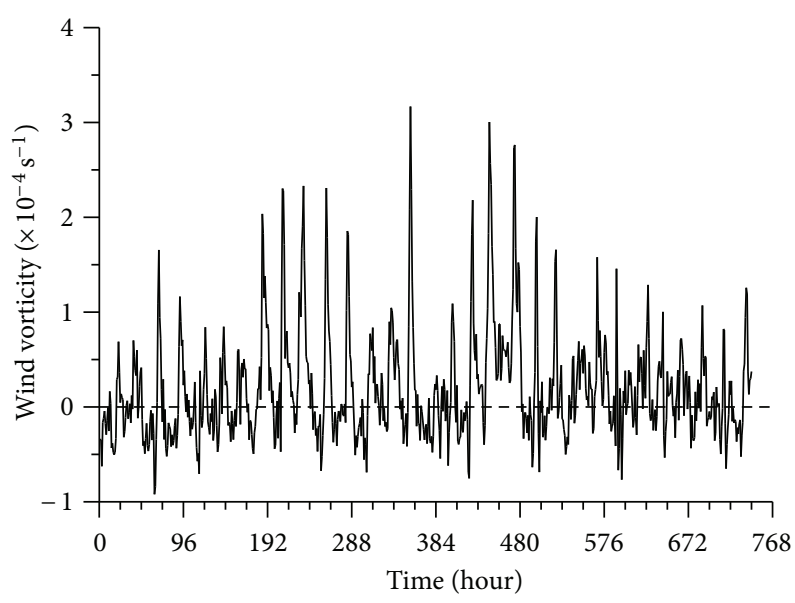

(d)

FIGURE 2: Results of the 1-cell lattice wind model applied to Mexico City. Time series of the wind state parameters (wind speed, wind direction, wind divergence, and wind vorticity) for March 2006.

The corresponding set of DWS was also determined and analyzed to estimate their occurrence probabilities during specific time periods of the day and different conditions, such as the presence or absence of sunlight.

6.1.1. Mexico City Wind States for March 2006. For each hour of March 2006, the local wind state of Mexico City can be obtained from the plots of Figure 2. In this period, the mean wind velocity was blowing from North at $0.163 \mathrm{~m} / \mathrm{s}$, as obtained from the mean horizontal components; the mean wind speed, however, was $1.143 \mathrm{~m} / \mathrm{s}$. Mean wind divergence was $-6.564 \times 10^{-5} \mathrm{~s}^{-1}$ and mean wind vorticity was $1.975 \times 10^{-5} \mathrm{~s}^{-1}$. So, this period, in average, was characterized by low-intensity northerly convergent cyclonic winds. Moreover, the result shown in Figure 2 for wind divergence indicates that (as observed by Jáuregui in 1988 [4]) convergent flow prevailed not only during the night period, but was also present during most of the daylight hours, when it would be expected that turbulent mixing would tend to weaken the heat-island induced flow. On the other hand, it is worth mentioning that the time series of wind divergence revealed three main Fourier components with periods of 24,12 , and 6 hours, in decreasing order of importance. For the wind vorticity time series, on the other hand, the main Fourier component had also a $24 \mathrm{~h}$ period clearly defined. Several other important higher-frequency components were also identified, although with considerably smaller magnitudes.

6.1.2. The Complete Density of Discrete Wind States. In Figure 3, the total density of Mexico City DWS for March 2006 is shown. In the same figure, the first ten DWSs with the highest frequencies of occurrence are shown. They were, in decreasing order, the states: $110[1: 4: 0: 2], 117$ $[1: 5: 0: 0], 146[2: 0: 0: 2], 137[1: 7: 0: 2], 126[1: 6: 0: 0]$, $87[1: 1: 2: 0], 96[1: 2: 2: 0], 182[2: 4: 0: 2], 119[1: 5: 0: 2]$, and $128[1: 6: 0: 2]$. They comprise $49.4 \%$ of the total number of wind events (744) that occurred in Mexico City during the MILAGRO campaign. In Table 2, the main attributes of these states are briefly described. 




(a)

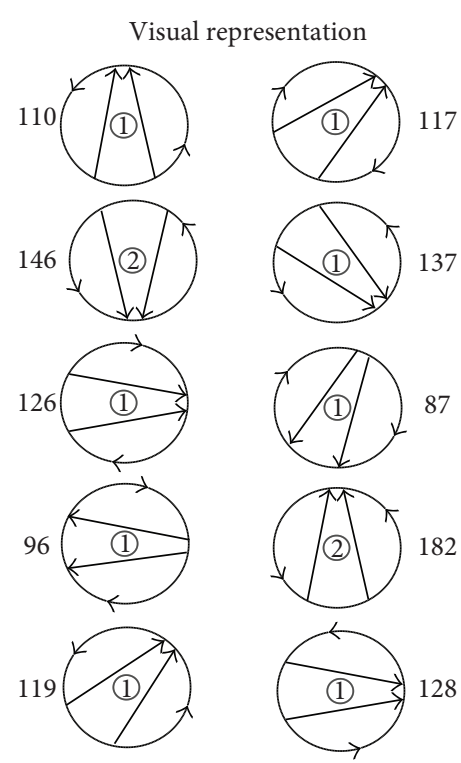

(b)

FIGURE 3: One-cell lattice wind model. (a) Complete density of DWS occurred in Mexico City during March 2006. (b) Visual representation of the DWS. The number inside the small circle indicates the intensity of wind in the Beaufort scale; the oriented circle represents wind vorticity; the couple of arrows indicates wind direction and divergence. The decimal IDs of the DWS were assigned according to (1).

TABLE 2: The first ten discrete wind states with the highest frequencies.

\begin{tabular}{|c|c|c|c|c|c|c|}
\hline State number & {$[U: \theta: \gamma: \omega]$} & Frequency (\%) & WSP $(\mathrm{m} / \mathrm{s})$ & WDR & WDIV & WVOR \\
\hline 110 & {$[1: 4: 0: 2]$} & 6.45 & $0.25 \leq v<1.5$ & $S$ & Convergent & Cyclonic \\
\hline 117 & {$[1: 5: 0: 0]$} & 6.45 & $0.25 \leq v<1.5$ & SW & Convergent & Anticyclonic \\
\hline 146 & {$[2: 0: 0: 2]$} & 5.91 & $1.5 \leq v<3.5$ & $\mathrm{~N}$ & Convergent & Cyclonic \\
\hline 137 & {$[1: 7: 0: 2]$} & 5.65 & $0.25 \leq v<1.5$ & NW & Convergent & Cyclonic \\
\hline 126 & {$[1: 6: 0: 0]$} & 5.38 & $0.25 \leq v<1.5$ & W & Convergent & Anticyclonic \\
\hline 87 & {$[1: 1: 2: 0]$} & 4.84 & $0.25 \leq v<1.5$ & $\mathrm{NE}$ & Divergent & Anticyclonic \\
\hline 96 & {$[1: 2: 2: 0]$} & 3.90 & $0.25 \leq v<1.5$ & $\mathrm{E}$ & Divergent & Anticyclonic \\
\hline 182 & {$[2: 4: 0: 2]$} & 3.90 & $1.5 \leq v<3.5$ & $S$ & Convergent & Cyclonic \\
\hline 119 & {$[1: 5: 0: 2]$} & 3.76 & $0.25 \leq v<1.5$ & SW & Convergent & Cyclonic \\
\hline 128 & {$[1: 6: 0: 2]$} & 3.09 & $0.25 \leq v<1.5$ & $\mathrm{~W}$ & Convergent & Cyclonic \\
\hline
\end{tabular}

WSP: wind speed, WDR: wind direction, WDIV: wind divergence, and WVOR: wind vorticity.

Among the first ten DWSs with the highest frequencies there were four states $(110,117,182$, and 119) that represent wind events with a flow component from South, three states $(87,137$, and 146) with a flow component from north, five states $(117,137,126,119$, and 128) with a flow component from west, and two states (87 and 96) with a flow component from east. We observed also that eight of these DWSs were convergent, and six were cyclonic.

In Figure 4, the statistical behaviors of state parameters during the study period are presented separately. Wind events had speeds predominantly within the level 1 of Beaufort scale (around $65 \%$ of the wind speed events); the N, S, SW, and $\mathrm{NE}$ were the main wind directions, with frequencies around $20 \%, 16 \%, 15 \%$, and $13 \%$, respectively; $75 \%$ of the DWSs represented winds with convergent features; $55 \%$ of wind states had cyclonic (positive) vorticity.
The set of DWS obtained for March 2006 represent wind events with speed ranging from 0 to $5.50 \mathrm{~m} / \mathrm{s}$. States with speeds from 0.25 to $1.5 \mathrm{~m} / \mathrm{s}$ (level 1 of the Beaufort scale) were found predominant, followed by states with speeds from 1.5 to $3.5 \mathrm{~m} / \mathrm{s}$ (Beaufort, level 2), and states with speeds from 0 to $0.25 \mathrm{~m} / \mathrm{s}$ (Beaufort, level 0).

6.1.3. Some Partial Densities of Discrete Wind States. The Mexico City's geographic location, the long and high mountains that surround it and the strong solar radiation it receives throughout the year, very frequently, establish ideal conditions for thermally driven winds. In order to identify the DWSs which are driven by these conditions and in response to the presence or absence of sunlight, we analyzed partial densities of states associated with day periods of early morning, morning, afternoon, and night, which, in 
$U$

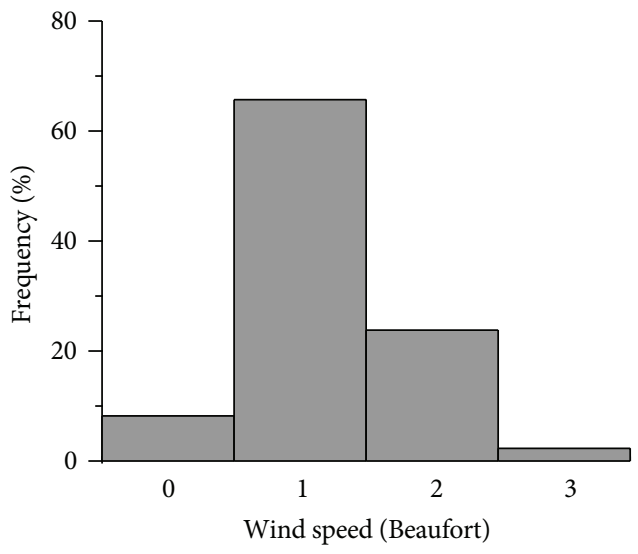

(a)

$\gamma$



(c)

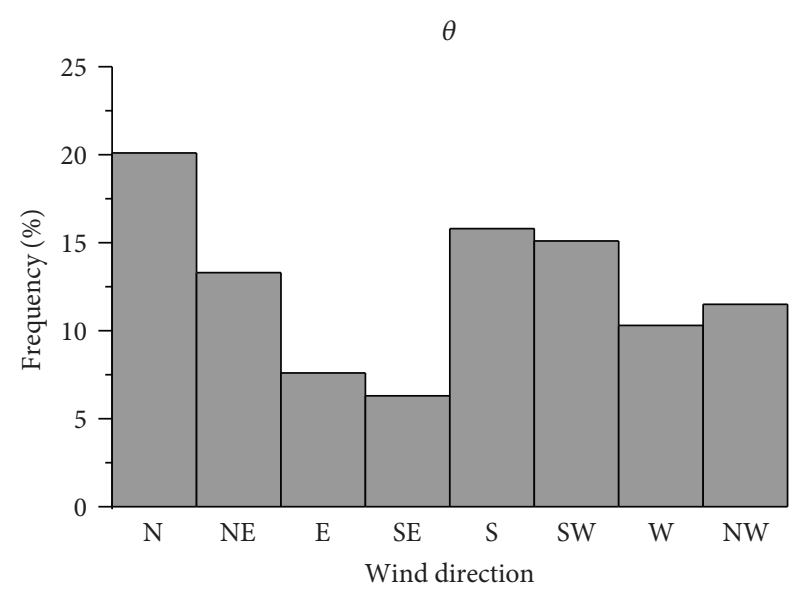

(b)

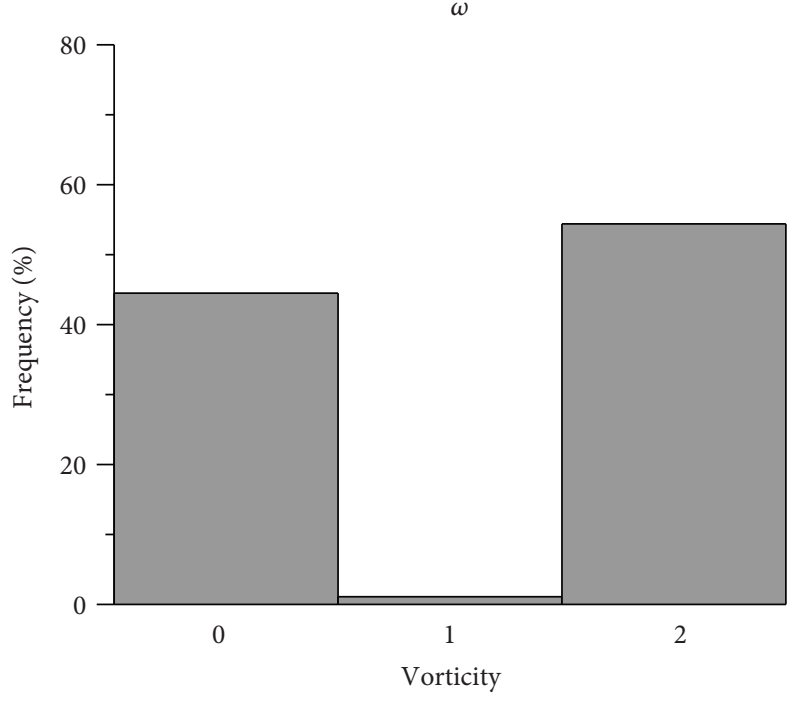

(d)

Figure 4: Frequency distributions of the state parameters $(U, \theta, \gamma$, and $\omega)$ relative to the whole set of the states that took place in Mexico City during March 2006.

local standard time, correspond to the following four 6-hour groups: $00-05 \mathrm{~h}, 06-11 \mathrm{~h}, 12-17 \mathrm{~h}$, and $18-23 \mathrm{~h}$, respectively. Here, the hour ID hh $(\mathrm{hh}=00,01, \ldots, 23)$ denotes a onehour period that starts at hh; for example, 05 hour denotes the period from 05:00:00 to 05: 59: 59 hours.

In Figure 5, the plots of partial densities of states for early morning, morning, afternoon, and night are shown, and in Figure 7, the main attributes of the first five DWSs with the highest frequencies of occurrence are presented for each time period. The top axis in the plots indicates the level of the Beaufort scale to which the DWS (indicated at the bottom axis) belong. The occurrence frequencies are relative to the total number of wind events registered during March 2006.

In the plots of DWS partial densities (Figure 5), it is observed immediately that only winds with speeds within the first 4 levels of the Beaufort scale were present in Mexico City during March 2006. Low-speed winds (0-0.25 m/s) appeared mainly during early morning and morning, while the wind conditions with higher speeds $(1.5-5.5 \mathrm{~m} / \mathrm{s})$ prevailed during afternoon and night.

With reference to Figure 7, it is observed that DWS with the highest frequencies along the nocturnal intervals were the states identified with numbers $117,126,110,119$, and 137 for the early morning, and 146, 137, 110, 209, and 182 states for the night. All DWS correspond to convergent winds with vorticity predominantly cyclonic and blowing mainly from S, NW, and SW sectors of the city. The states represent typical nocturnal winds coming down to Mexico City from the nearest surrounding mountains (katabatic winds). On the other hand, during the sunlight hours the highest frequencies states were those identified as $96,87,78,117$, and 81 for the morning, and the $87,182,146,110$, and 96 states for the afternoon. The 96 and 87 states were present during all the sunlight hours; along with 78 state, they correspond to 


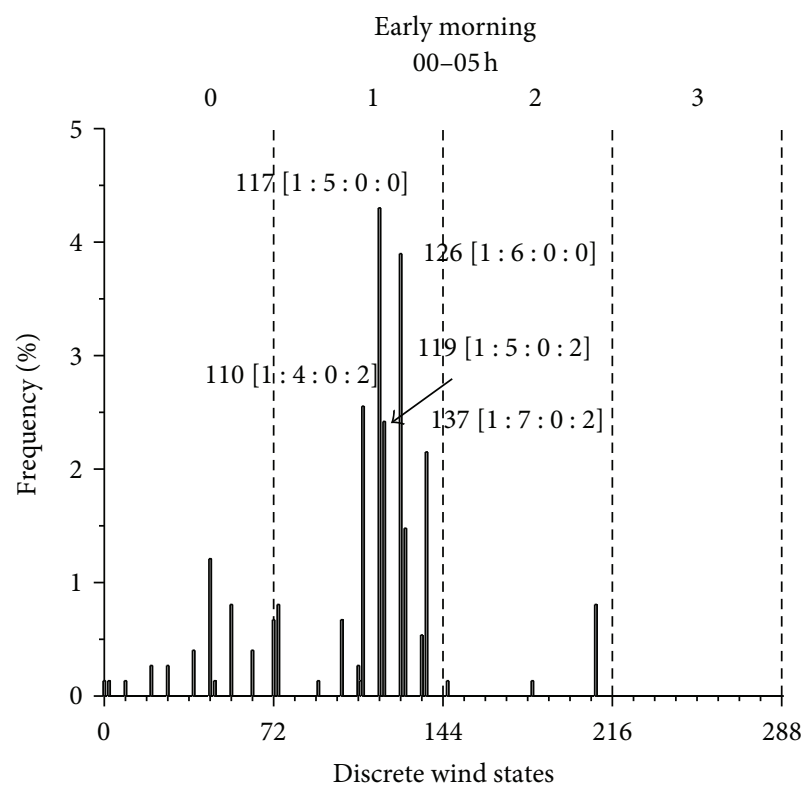

(a)



(c)

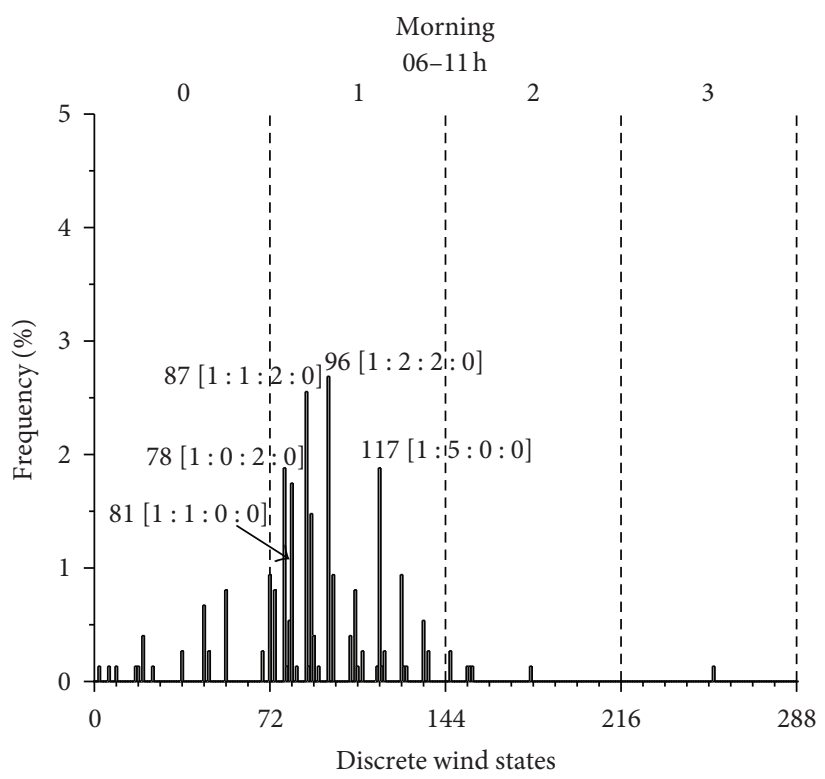

(b)



(d)

FIGURE 5: Occurrence frequencies of the Mexico City discrete wind states for March 2006 day periods of early morning (00-05 h), morning (06-11 h), afternoon (12-17 h), and night (18-23 h). The decimal IDs of the DWS were assigned according to (1).

divergent winds with anticyclonic vorticity going up from the city area towards the surrounding mountains (anabatic winds) located at the W, SW, and S city boundaries. The other five main states, which took place during the sunlight hours $(117,81,182,146$, and 110), correspond to convergent winds, in the anticyclonic state for the morning (117 and 81) and cyclonic for the other three.

In Figure 6(a), it is observed that the occurrence frequency of convergent states $(\gamma=0)$ had its highest values on nighttime; it started to decrease very fast from the sunrise, kept low values during the hours around midday, and it increased from the first hours of afternoon to the sunset. The divergent states $(\gamma=2)$, on the other hand, showed an opposed and complementary behavior along the day. This behavior of Mexico City winds is typical of the mountainvalley systems. However, it is interesting to highlight that convergent wind during sunlight hours could be considered as an evidence of an urban heat island effect in Mexico City, as it has been suggested by Jáuregui $[4,5]$.

In Figure 6(b), it is observed that the occurrence frequency of cyclonic states $(\omega=0)$ started to grow from the first hours of the day, reaching its highest value at sunrise, 

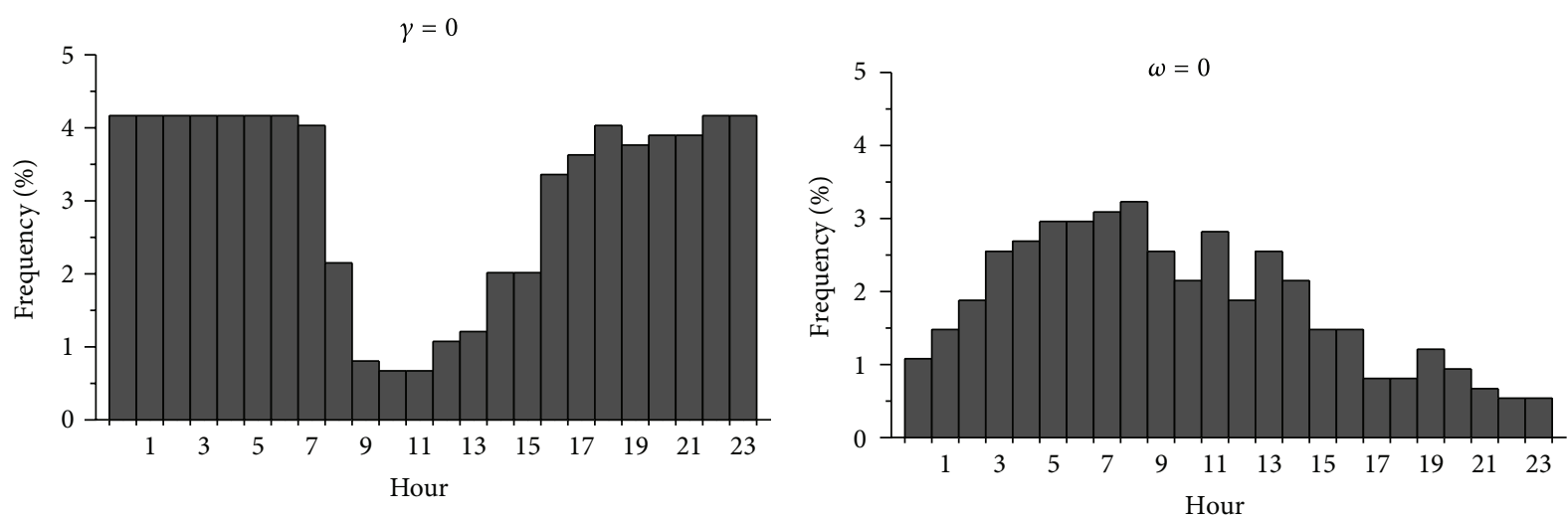

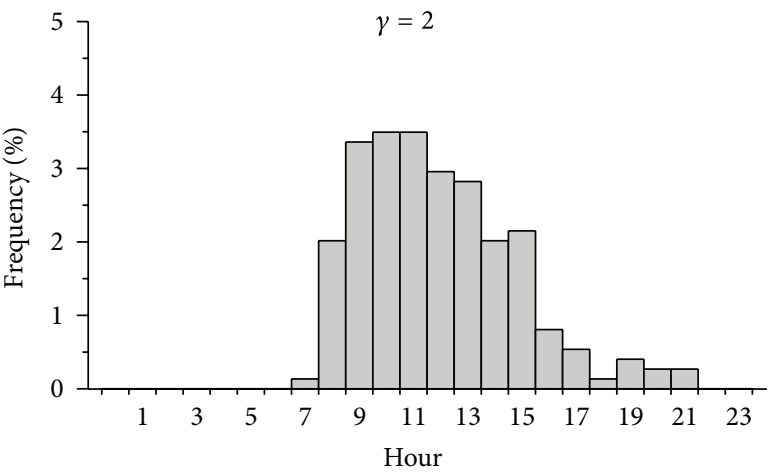

(a)



(b)

Figure 6: (a) Hourly distribution of the occurrence frequency of the Mexico City discrete wind states during March 2006 with respect to wind divergence. Top: convergent states. Bottom: divergent states. These results are consistent with upslope wind during day (divergent) and downslope wind at night (convergent). (b) Hourly distribution of the occurrence frequency of the Mexico City discrete wind states during March 2006 with respect to wind vorticity. Top: anticyclonic (negative) vorticity states. Bottom: cyclonic (positive) vorticity states.

and then decreased slowly, reaching its smallest values at midnight. Anticyclonic states $(\omega=2)$ presented an opposed and complementary behavior along the day.

Results presented in the Figures 6(a) and 6(b), so as those of Figure 2, underline that Mexico City winds presented a diurnal cycle behavior during March 2006 with respect to divergence and vorticity wind-state parameters. It can be stressed that the diurnal cycle behavior of Mexico City winds with respect to the vertical wind vorticity has never been reported before.

6.1.4. Northerly and Southerly Winds. Mexico City is located inside a subtropical basin surrounded almost completely by high mountains. To the north, the basin extends into the Mexican plateau with the Sierra de Guadalupe, creating a natural small barrier of $800 \mathrm{~m}$ high above the ground. To the south, the Sierra del Ajusco-Chichinautzin extends from west to east up to $98.9^{\circ} \mathrm{W}$, approximately, and thereafter the altitude decreases below the $2500 \mathrm{~m}$, creating a mountain gap of $22 \mathrm{~km}$ long which ends at the Iztaccihuatl volcano. The topographic features of Mexico City Area set up a wind corridor north-south, which is the main mechanism to ventilate the city. The northerly and southerly winds in the region are important because of the exchange of air pollution between Mexico City and the human settlements located to the north and the south of the city.

During March 2006, DWS associated with northerly and southerly winds in Mexico City had occurrence frequencies of $20 \%$ and $16 \%$, respectively, as it was shown in Figure 4 . So $36 \%$ of DWS contributed strongly to ventilate the city during the study period, but also to export air pollutants to the neighboring northern and southern settlements.

The DWSs named as 110, 117, 182, and 254 belong to states that obtained the highest occurrence frequencies in this period $(6.5,6.5,3.9$, and $0.9 \%$, resp., see Figure 7$)$. The states represent winds with a flow component from south, which are the kind of winds that were expected to prevail during the MILAGRO 2006 campaign. Wind events like these were identified on March 9 during 19 hours (from 00 to $06 \mathrm{~h}$ and from 12 to $23 \mathrm{~h}$ ). In Figure 8, the set of DWS occurred this day is described.

On the other hand, 137, 87, 78, 81, 146, and 209 states represent winds with a flow component from north and were found among the DWS with the highest occurrence frequencies (see Figure 7). Wind events like those were found on March 5 from 08 to $23 \mathrm{~h}$. In Figure 9, the set of DWS occurred this day is described. 

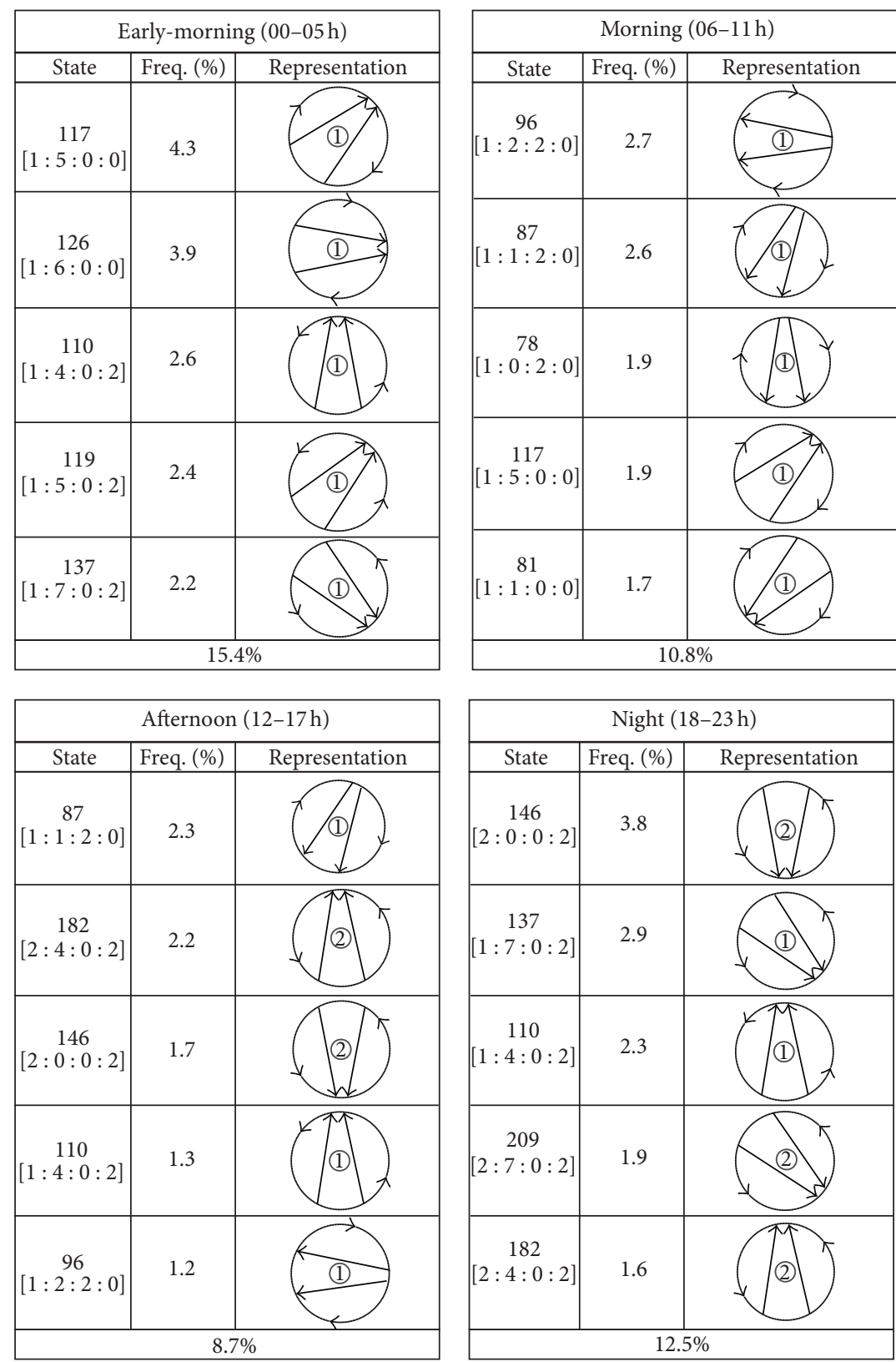

FIGURE 7: First five discrete wind states with the highest occurrence frequencies during the March 2006 time periods of early morning, morning, afternoon, and night.

6.2. Preliminary Results from the 4-Cell Model. Within the framework of the 4-cell lattice wind model, the Mexico City area is modeled as a 2D lattice with four identical cells, which represent NE, NW, SW, and SE quadrants of the city. The wind state at each cell is described, as in the 1-cell model, by four parameter $(U, \theta, \gamma$, and $\omega)$, whose values are considered as spatial averages over the cell. The wind state of the system is now represented by four cell wind states:

$$
\xi=\left[\begin{array}{cc}
(U, \theta, \gamma, \omega)_{\mathrm{NW}} & (U, \theta, \gamma, \omega)_{\mathrm{NE}} \\
(U, \theta, \gamma, \omega)_{\mathrm{SW}} & (U, \theta, \gamma, \omega)_{\mathrm{SE}}
\end{array}\right] .
$$

This description, because of the topographic complexity in the region, is particularly useful in the case of Mexico City.
Figure 10 presents the hourly wind states occurred on March 19, 2006. This day is particularly interesting for the purposes of MILAGRO campaign because the DWS describe winds blowing from south of the city, or at least, with flow components from the south, for 21 hours. The wind behavior during that day was classified by Voss et al. [16], based on experimental results obtained with free-floating altitude controlled balloons, as one of the most significant outflow events during MILAGRO field campaign. The DWSs with different wind flow characteristics were those of the morning from 04 to $07 \mathrm{~h}$, which very clearly present convergent features of Mexico City katabatic winds. It is worth mentioning that starting from $07 \mathrm{~h}$ up to the end of the day the wind 

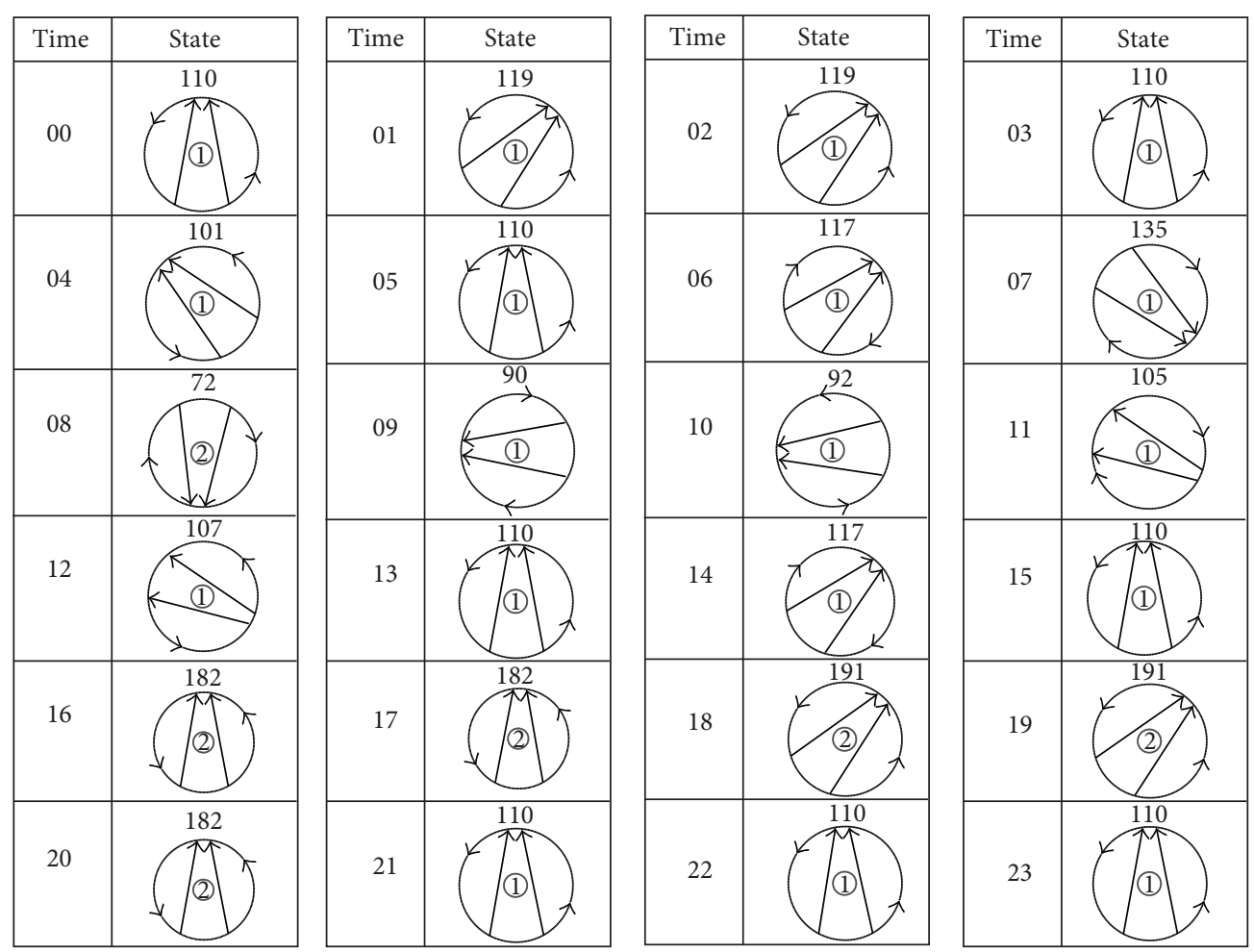

FIGURE 8: The set of discrete wind states occurred on March 9, 2006. Predominance of DWS with a flow component from south is observed.
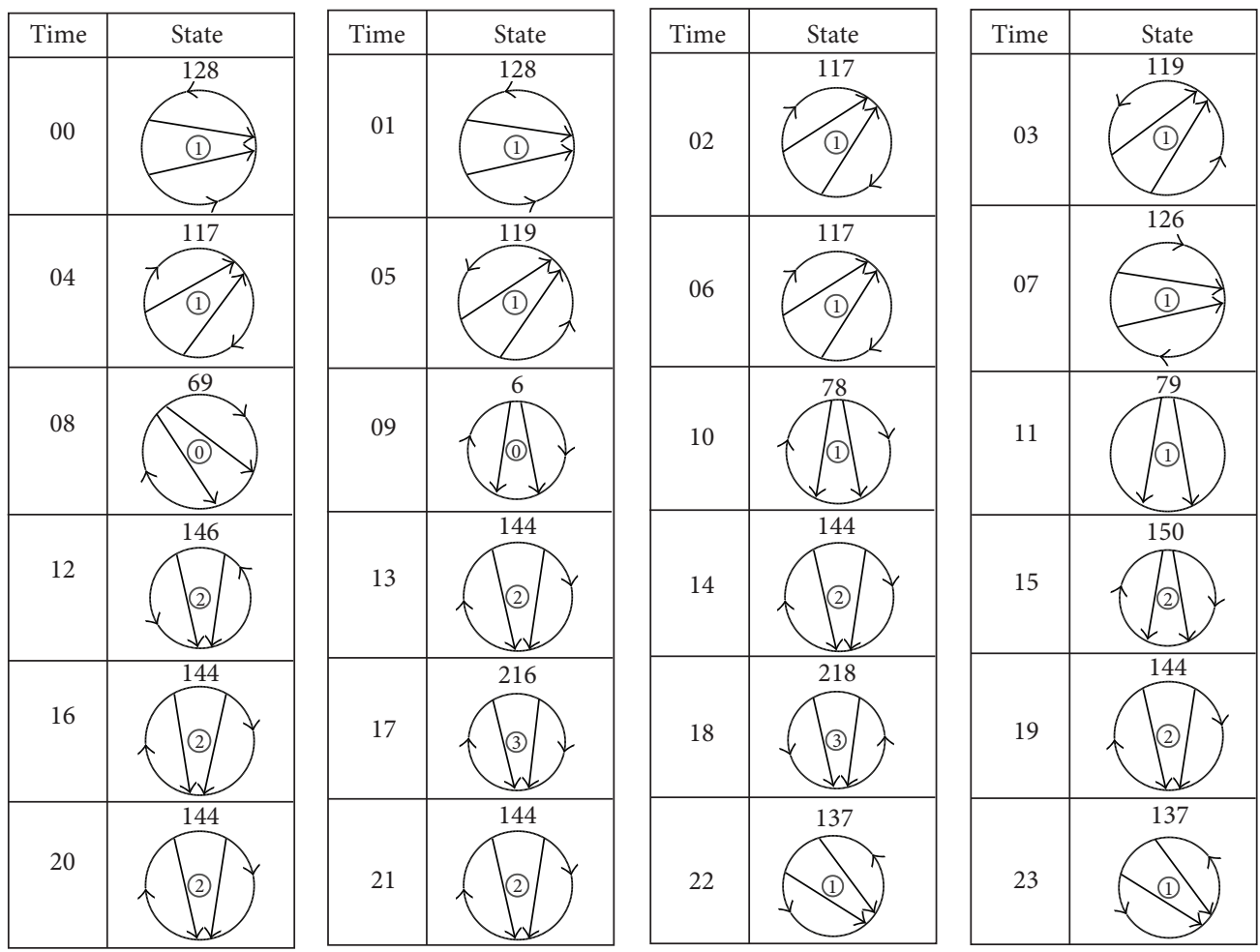

FIGURE 9: The set of discrete wind states occurred on March 5, 2006. Predominance of DWS with a flow component from north is observed. 

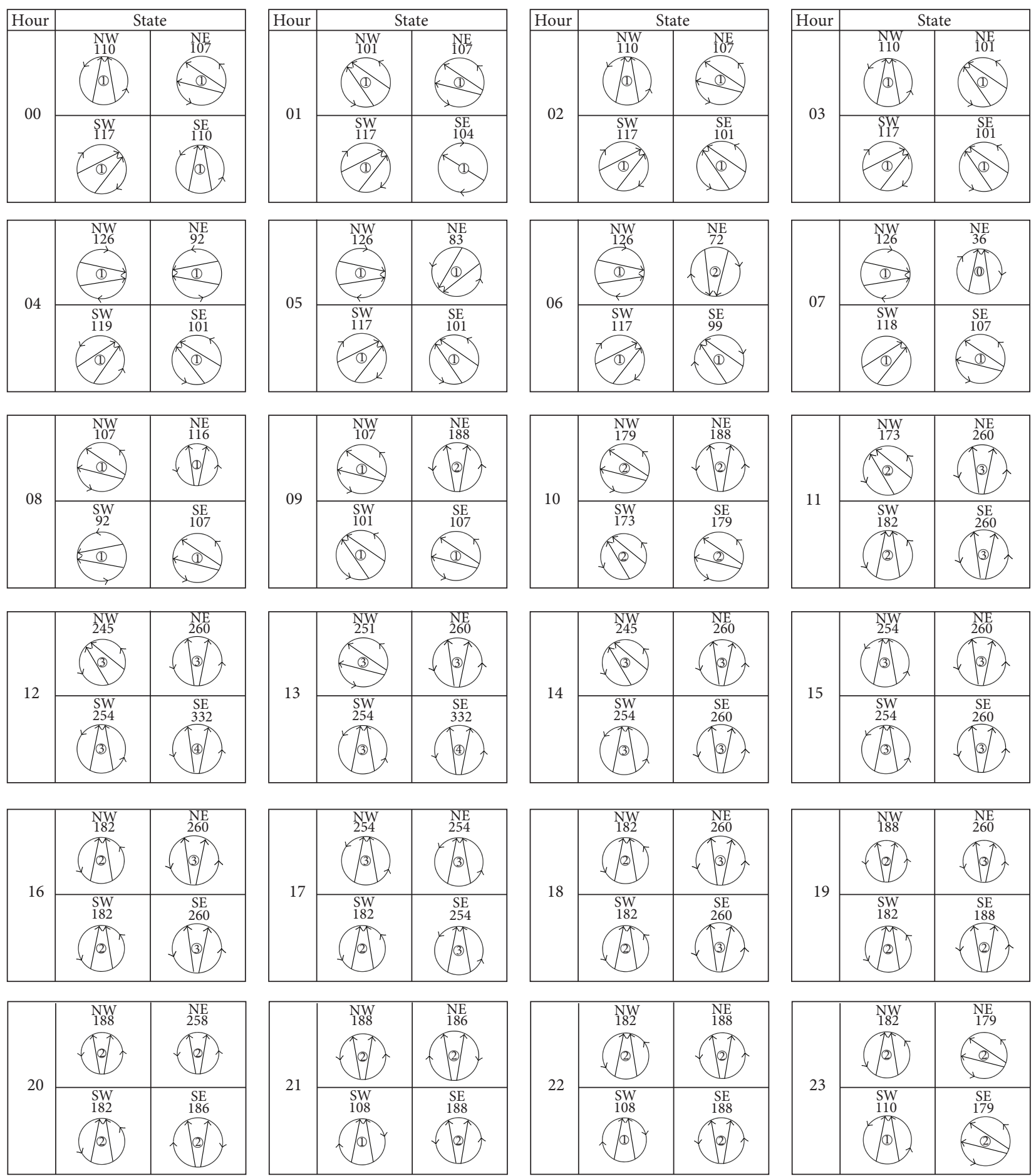

Figure 10: Discrete wind states occurred in Mexico City during March 19, 2006. 4-cell model.

state in the SE quadrant of the city represents divergent winds blowing from south or southeast. These features of the DWS at SE quadrant disclose that they correspond to gap winds coming into the city through the mountain gap located between the Sierra Ajusco-Chichinautzin and the Iztaccihuat volcano. Recognizing the gap winds reveals the convenience of using the 4-cell model for better identifying the Mexico City wind patterns.

\section{Conclusions}

In this work, we described a lattice wind modeling approach at a meso- $\beta$ scale proposed by Salcido et al. [1-3]. It was applied for identifying the main characteristics of wind events that prevailed in Mexico City during the MILAGRO field campaign (March 2006). The study was performed with the hourly wind data provided by the meteorological subnetwork 
(REDMET) of the official atmospheric monitoring network (SIMAT) of the Mexico City Metropolitan Area. Because of the systematic availability of reliable and high-quality wind data at REDMET, consideration of studies for longer time periods does not imply additional technical problems. This modeling approach has been applied recently for identifying and selecting of meteorological scenarios in air quality assessment studies [18, 19].

Only results from the simplest lattice wind models (those with 1 and 4 lattice cells) were considered in this work. In spite of the conceptual simplicity of the model, its results allowed recognizing of some of the main features of wind circulation in Mexico City during March 2006. In particular, the following features can be underlined.

(a) Predominance (66\%) of wind events with speeds ranging from 0.25 to $1.50 \mathrm{~m} / \mathrm{s}$. The wind states with the lowest speeds $(0-0.25 \mathrm{~m} / \mathrm{s})$ appeared mainly during the early morning and Morning time periods, while the states with the highest speeds $(1.50-5.50 \mathrm{~m} / \mathrm{s})$ occurred especially during afternoon and night.

(b) Predominance $(20 \%)$ of northerly wind events followed by the southerly, southwesterly, and northeasterly wind events, with frequencies of $16 \%, 15 \%$, and $13 \%$, respectively.

(c) The presence of winds events driven thermally by combination of mountain-valley effects (derived from the presence of high mountains surrounding the Basin of Mexico), and the urban heat island effects (derived from the large extension of urban surface in the city and the large area of rural soil in the surroundings). The combination of those effects led to the occurrence of convergent winds with a frequency of $75 \%$, with predominance during the nocturnal hours (katabatic winds), but also with considerable presence during the sunlight hours (urban heat island winds).

(d) A slight prevalence of wind events with cyclonic (positive) vorticity (55\%). Mexico City wind events revealed the existence of a diurnal cycle in wind vorticity, where the anticyclonic wind states presented an hourly distribution accumulated around the sunrise, while the hourly distribution of cyclonic wind states appeared accumulated around midnight.

(e) The presence of gap winds at southeast sector of the city as a consequence of the mountain gap $22 \mathrm{~km}$ long located between the Ajusco-Chichinautzin and the Iztaccihuatl mountains. The main feature of wind states associated to the gap winds was the presence of divergent wind states in the SE quadrant of the city representing divergent local winds blowing from south or southeast. This class of winds was identified within the framework of the 4-cell lattice wind model.

(f) Divergence and vorticity of the Mexico City wind reflected the effect of the diurnal cycle of incoming solar radiation, which is revealed by the main Fourier component (having a $24 \mathrm{~h}$ period) of their time series. The time series of wind divergence, in addition, reveals also an important Fourier component with a $12 \mathrm{~h}$ period, which presumably is induced by the presence of a heat island phenomenon in the city.

\section{Acknowledgments}

Enlightening comments and helpful suggestions from Sasha Madronich (National Center for Atmospheric Research, USA) are acknowledged. Collaboration of M. I. Saavedra (CCA-UNAM, Mexico) and R. Villegas-Martínez (IIE, Mexico) in organizing and preparing the REDMET-SIMAT meteorological data for the modeling purposes is also acknowledged.

\section{References}

[1] A. T. Celada and A. Salcido, "The Mexico City 2006 wind direction states," in Proceedings of the 20th IASTED International Conference on Modelling and Simulation, pp. 51-58, Banff, Canada, July 2009.

[2] A. Salcido and A. T. Celada, "A lattice gas approach to the Mexico City wind field estimation problem," in Modelling, Simulation and Optimization, G. Romero Rey and L. M. Muneta, Eds., pp. 385-416, InTech, Vienna, Austria, 2010.

[3] A. Salcido, A. T. Celada, and T. Castro, "A meso- $\beta$ scale description of surface wind events in Mexico City during MILAGRO 2006 campaign," in Proceedings of the 2nd IASTED International Conference on Environmental Management and Engineering, pp. 820-827, Banff, Canada, July 2010.

[4] E. Jáuregui, "Local wind and air pollution interaction in the Mexico basin," Atmósfera, vol. 1, no. 3, pp. 131-140, 1988.

[5] E. Jáuregui, "Heat island development in Mexico City," Atmospheric Environment, vol. 31, no. 22, pp. 3821-3831, 1997.

[6] J. E. Bossert, "An investigation of flow regimes affecting the Mexico City region," Journal of Applied Meteorology, vol. 36, no. 2, pp. 119-140, 1997.

[7] J. D. Fast and S. Y. Zhong, "Meteorological factors associated with inhomogeneous ozone concentrations within the Mexico City basin," Journal of Geophysical Research, vol. 103, no. 15, pp. 18927-18946, 1998.

[8] J. C. Doran, S. Abbott, J. Archuleta et al., "The IMADA-AVER boundary layer experiment in the Mexico City Area," Bulletin of the American Meteorological Society, vol. 79, no. 11, pp. 2497-2508, 1998.

[9] A. Salcido, A. T. Celada, R. Villegas-Martínez, H. Salas-Oviedo, R. Sozzi, and T. Georgiadis, "A micrometeorological data base for the Mexico City Metropolitan Area," Il Nuovo Cimento C, vol. 26, no. 3, pp. 317-355, 2003.

[10] A. Salcido, R. Sozzi, and T. Castro, "Least squares variational approach to the convective mixing height estimation problem," Environmental Modelling and Software, vol. 18, no. 10, pp. 951-957, 2003.

[11] B. de Foy, E. Caetano, V. Magaña et al., "Mexico City basin wind circulation during the MCMA-2003 field campaign," Atmospheric Chemistry and Physics, vol. 5, no. 8, pp. 2267-2288, 2005.

[12] J. D. Fast, B. de Foy, F. Acevedo-Rosas et al., "A meteorological overview of the MILAGRO field campaigns," Atmospheric Chemistry and Physics, vol. 7, no. 9, pp. 2233-2257, 2007. 
[13] B. de Foy, J. D. Fast, S. J. Paech et al., "Basin-scale wind transport during the MILAGRO field campaign and comparison to climatology using cluster analysis," Atmospheric Chemistry and Physics, vol. 8, no. 5, pp. 1209-1224, 2008.

[14] A. Salcido, "A non local equilibrium model for the constitutive equations of a non-uniform simple fluid," in Proceedings of the 2nd IASTED International Symposium on Modern Nonlinear Theory (MNT'08), pp. 339-344, usa, November 2008.

[15] Secretaría del Medio Ambiente and Gobierno del Distrito Federal, Informe Climatológico Ambiental de la Cuenca del Valle de México, 2001.

[16] P. B. Voss, R. A. Zaveri, F. M. Flocke et al., "Long-range pollution transport during the MILAGRO-2006 campaign: a case study of a major Mexico City outflow event using freefloating altitude-controlled balloons," Atmospheric Chemistry and Physics, vol. 10, no. 15, pp. 7137-7159, 2010.

[17] Sistema de Monitoreo Atmosférico de la Ciudad de México (SIMAT), "Secretaría del Medio Ambiente. Gobierno de la Ciudad de México," http://www.calidadaire.df.gob.mx/calidadaire/, 2011.

[18] D. Salcedo, T. Castro, L. G. Ruiz-Suárez et al., "Study of the regional air quality south of Mexico City (Morelos state)," Science of the Total Environment, vol. 414, pp. 417-432, 2012.

[19] O. Peralta, T. Castro, M. Durón et al., "H2S emissions from Cerro Prieto geothermal power plant, Mexico, and air pollutants measurements in the area," Geothermics, vol. 46, pp. 55-65, 2013. 



The Scientific World Journal
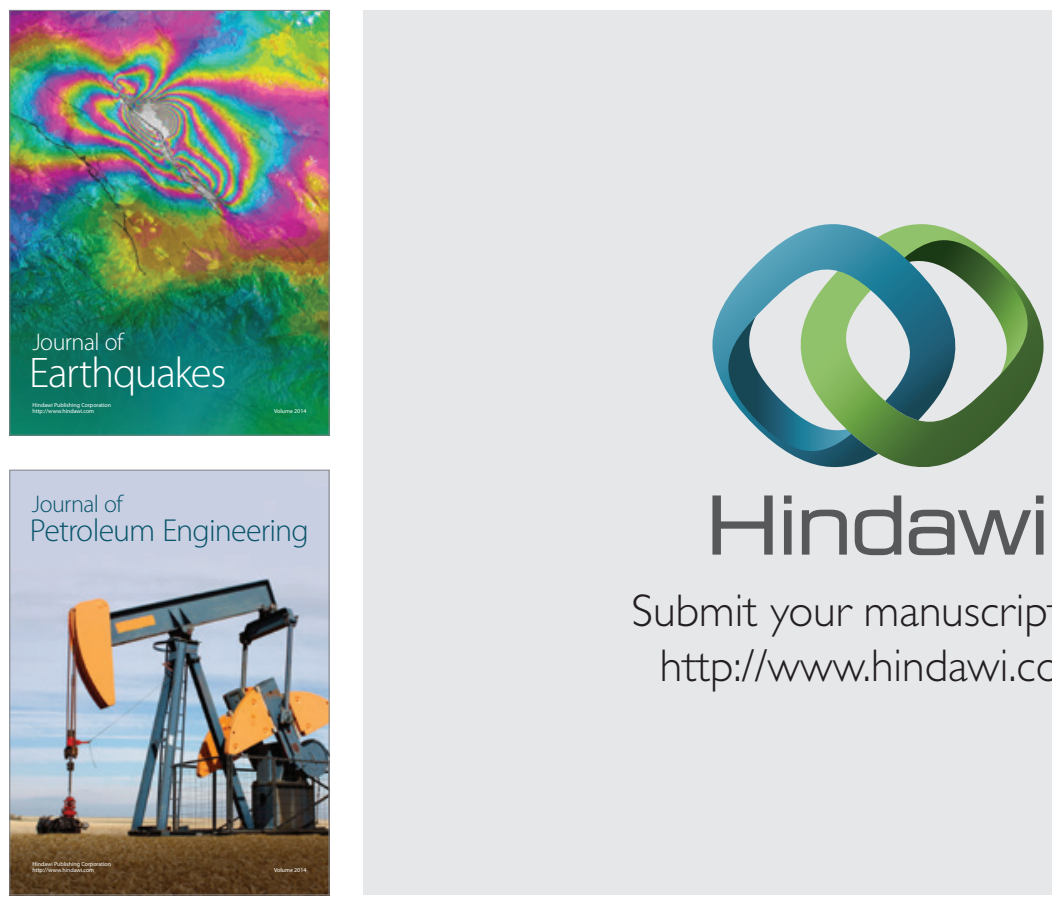



Submit your manuscripts at

http://www.hindawi.com
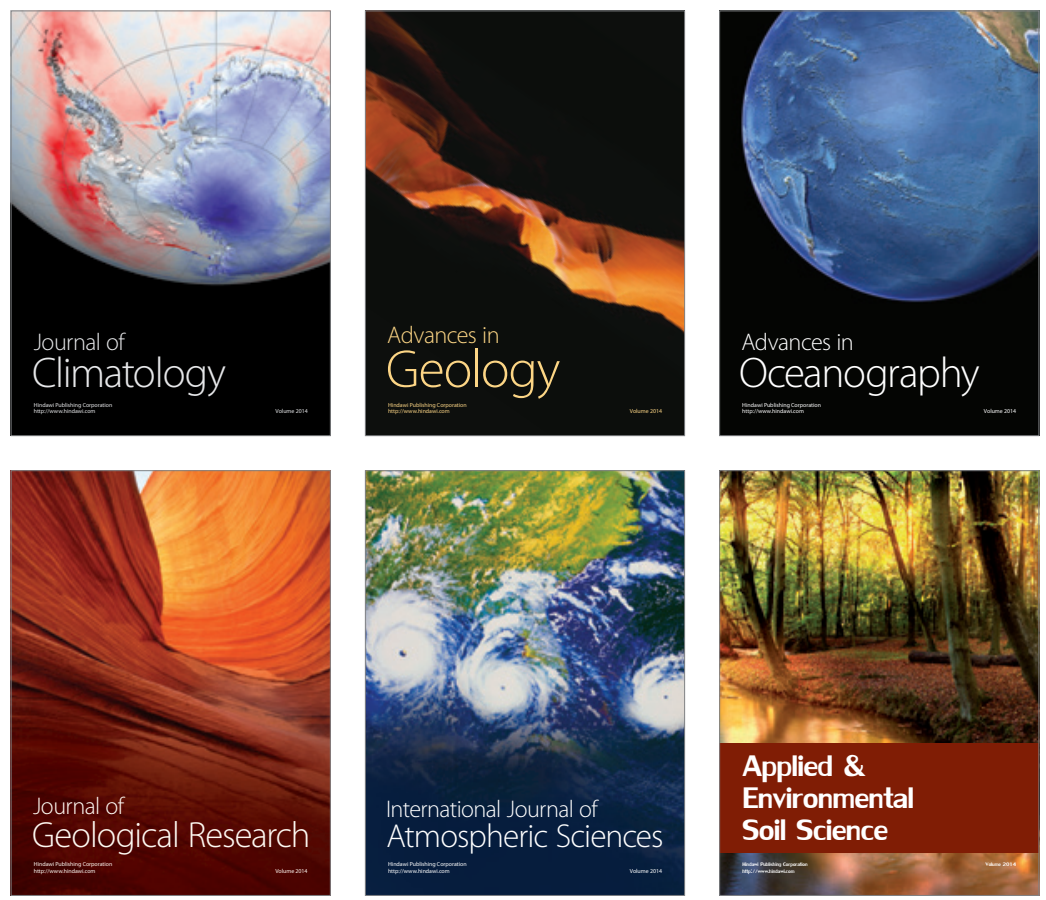
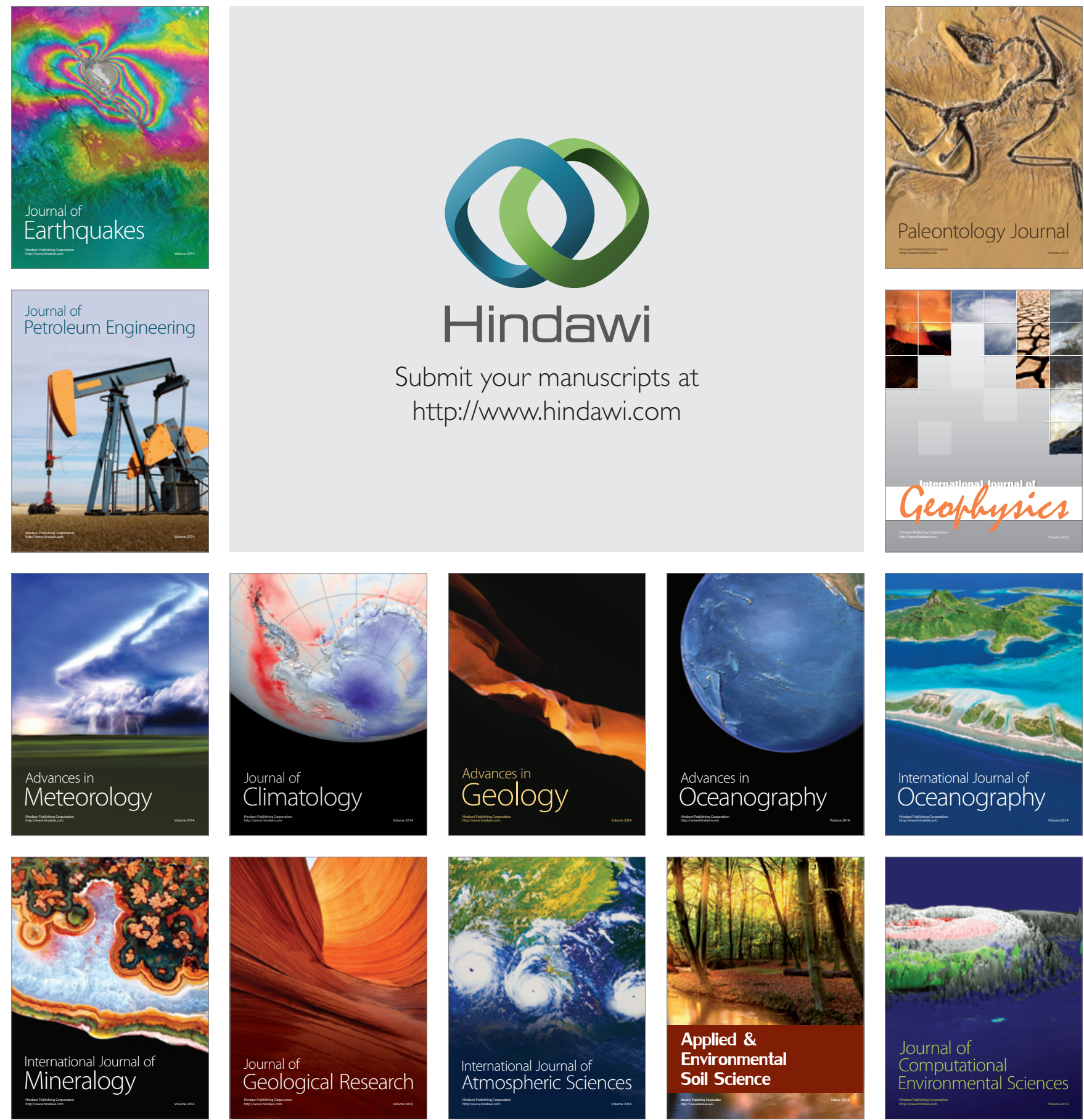